Article

\title{
Acute Effects of Single Doses of Bonito Fish Peptides and Vitamin D on Whole Blood Gene Expression Levels: A Randomized Controlled Trial
}

\author{
Frédéric Guénard ${ }^{1,2}{ }^{-}$, Hélène Jacques ${ }^{1,2}$, Claudia Gagnon ${ }^{2,3,4}$, André Marette ${ }^{2,5}$ \\ and Marie-Claude Vohl $1,2, * \mathbb{D}$ \\ 1 School of Nutrition, Laval University, 2440 Hochelaga Blvd, Quebec, QC G1V 0A6, Canada; \\ frederic.guenard@fsaa.ulaval.ca (F.G.); Helene.Jacques@fsaa.ulaval.ca (H.J.) \\ 2 Institute of Nutrition and Functional Food (INAF), Laval University, 2440 Hochelaga Blvd, Quebec, QC G1V \\ 0A6, Canada; Claudia.Gagnon@crchudequebec.ulaval.ca (C.G.); andre.marette@criucpq.ulaval.ca (A.M.) \\ 3 Endocrinology and Nephrology Unit, CHU de Quebec Research Center, 2705 Laurier Blvd, \\ Quebec, QC G1V 4G2, Canada \\ 4 Department of Medicine, Laval University, 1050 avenue de la Médecine, Quebec, QC G1V 0A6, Canada \\ 5 Quebec Heart and Lung Institute (IUCPQ) Research Center, 2725 chemin Sainte-Foy, \\ Quebec, QC G1V 4G5, Canada \\ * Correspondence: Marie-Claude.Vohl@fsaa.ulaval.ca
}

Received: 25 March 2019; Accepted: 19 April 2019; Published: 20 April 2019

\begin{abstract}
Fish contains high quality proteins and essential nutrients including 25-hydroxyvitamin D (25(OH)D). Fish peptide consumption can lower cardiovascular disease (CVD) risk factors, and studies have shown an association between 25(OH)D deficiency, CVD and CVD risk factors, such as diabetes. This study investigated acute effects of a single dose of cholecalciferol $\left(\mathrm{VitD}_{3}\right)$, bonito fish peptide hydrolysate (BPH), or a combination of both on CVD risk factors and whole blood gene expression levels. A randomized, crossover, placebo controlled trial was conducted in 22 adults. They ingested, in random order and at 7-day intervals, $1000 \mathrm{IU}$ of $\mathrm{VitD}_{3}, 3 \mathrm{~g}$ of BPH, a combination of both, or a placebo. A $180 \mathrm{~min}$ oral glucose tolerance test was performed. Differences in whole-genome expression levels after versus before each supplementation were computed for 18 subjects. We observed that 16,1 and 5 transcripts were differentially expressed post- vs. pre-ingestion for $\mathrm{VitD}_{3}, \mathrm{BPH}$ or $\mathrm{VitD}_{3}+\mathrm{BPH}$ treatments, respectively. $\mathrm{VitD}_{3}$-containing treatments affected the expression of the solute carrier family 25 member 20 (SLC25A20) gene involved in fatty acid oxidation, various transcription factors and genes related to glucose metabolism. These results suggest that $\mathrm{VitD}_{3}$ rapidly modulates genes related to CVD risk factors in blood while $\mathrm{BPH}$ seems to moderately modulate gene expression levels.
\end{abstract}

Keywords: cholecalciferol; gene expression; cardiometabolic risk; nutrigenomics

\section{Introduction}

Dietary habits influence diverse cardiometabolic risk factors, including cholesterol levels, blood pressure, glucose, and insulin homeostasis [1]. Observational studies and prospective epidemiological studies reported an association between high fish consumption and reduced mortality from coronary artery disease [2-4]. Inverse associations between fish consumption and the risk of all-cause mortality [5, 6], cardiovascular disease (CVD) [6], mortality and type 2 diabetes (T2D) [7] have been observed. Benefits from fish consumption were attributed to eicosapentaenoic acid (EPA, 20:5 (n-3)) and docosahexaenoic acid (DHA, 22:6 (n-3)) [2,3], but it was also proposed that the potential benefits of fish consumption may be related to other nutrients, such as vitamins and proteins $[8,9]$. Fish protein hydrolysates containing 
bioactive peptides were shown to possess promising properties for the prevention of CVD and risk management [9].

Regional differences were reported in the association between fish consumption and risk of mortality [6]. An inverse association between fish consumption and mortality risk was reported in Asian populations $[10,11]$ while such an association was not confirmed in Western populations [12,13], thus, suggesting that preparation method and/or fish type may have an impact on the health outcomes of fish consumption according to geographical regions [6]. Concordant with the latter suggestions, studies on lean fish or fish protein hydrolysates demonstrated specific effects for different fish species. Dietary cod proteins were shown to improve insulin sensitivity and reduce plasma C-reactive protein (CRP) in insulin-resistant individuals [14,15]. Clinical studies demonstrated a significant reduction in serum low-density lipoprotein (LDL)-cholesterol (C) following consumption of a cod-fish protein supplement in overweight adults with no effect on triglyceride (TG) or high-density lipoprotein-cholesterol (HDL)-C levels [16]. A decrease in systolic and diastolic blood pressure (SBP and DBP) has been reported in normotensive or moderately hypertensive individuals supplemented with bonito fish [17]. Similarly, studies in animal models have demonstrated that protein sources differ in their ability to modulate CVD risk factors including insulin sensitivity [18] and lipid levels [19]. A salmon protein hydrolysate was shown to reduce glucose intolerance, dyslipidemia, and adipose tissue inflammation in obese mice fed a high-fat, high-sucrose diet [20]. Similarly, a study conducted in rats comparing various protein sources (casein and fish proteins from bonito, herring, mackerel, or salmon) in high-fat, high-sucrose diet reported a decreased expression of the pro-inflammatory cytokines TNF- $\alpha$ and IL- 6 in fish-protein-fed groups [21], while lower weight gain, lower visceral adiposity, and improved insulin sensitivity were observed only in the salmon-protein fed group.

Low serum levels of 25-hydroxyvitamin D $(25(\mathrm{OH}) \mathrm{D})$ have been associated with mortality and deteriorated cardiovascular health reflected through unfavorable lipid profile, T2D, hypertension, and obesity [22-25]. 25(OH)D deficiency is highly prevalent in the general population, with a frequency about $30 \%$ to $50 \%$ [26] according to the generally accepted threshold level of 20 to $30 \mathrm{ng} / \mathrm{mL}$ (50-75 nmol/L) for sufficiency [27]. Discordant from the above-mentioned observations, randomized control trials (RCT) reported an increase in TG or LDL-C concentrations after cholecalciferol $\left(\mathrm{Vit}_{3}\right)$ supplementation [28,29], which was further confirmed in a meta-analysis [30]. In view of these reports, Ponda and collaborators [29] concluded that the benefit inferred from cross-sectional associations of higher $25(\mathrm{OH}) \mathrm{D}$ levels and a healthier lipid profile was not replicated by acute $\mathrm{Vit}_{3}$ repletion. Similarly, RCT also showed discordant results regarding the benefits of $\mathrm{Vit}_{3}$ supplementation on glucose homeostasis [31-33].

Based on the pleiotropic effects of 25(OH)D at transcriptomic level [34] and the association of 25(OH)D deficiency with multiple diseases [22-25], RCT assessed the impact of $\mathrm{Vit}_{3}$ supplementation on gene expression levels. Similar to RCT on metabolic parameters, long-term supplementation studies demonstrated discordant results at gene expression levels, some studies not supporting an impact $[35,36]$ while others reported important changes at genome-wide expression levels in healthy [37] and in metabolically deteriorated individuals [36,38].

While the risk of cardiometabolic diseases is predominantly influenced by specific foods and overall dietary patterns, assessing the impact of specific nutrients may be informative from a mechanistic point of view. Evaluating early changes in gene expression levels following nutritional treatments may reveal mediators of metabolic improvement observed under specific dietary patterns while limiting confounding factors. Therefore, the purpose of the current study was to investigate acute impacts of a single dose of $\mathrm{Vit}_{3}$, bonito fish peptide hydrolysate (BPH) or a combination of both, on cardiometabolic health factors and gene expression levels. A randomized, crossover, placebo controlled trial was conducted, thus, limiting inter-individual variability in the response to treatments. 


\section{Results}

\subsection{Participant Baseline Characteristics}

This study included 22 Caucasian adults (11 males, 11 females) aged 23 to 68 years (mean $47.5 \pm 14.2$ years). Anthropometric and metabolic parameters before each treatment period did not differ between treatments (Table 1). Similar concentrations of $25(\mathrm{OH}) \mathrm{D}$ were found before each treatment period, seven to nine individuals (30-40\%) showed deficiency in serum $\mathrm{VitD}_{3}$ levels $(<20 \mathrm{ng} / \mathrm{mL}$; $<50 \mathrm{nmol} / \mathrm{L})$. Following adjustment for age and sex, no significant associations were observed between baseline serum VitD 3 levels and metabolic profile (Total-C, LDL-C, HDL-C, TG levels, Total-C/HDL-C ratio, blood pressure, fasting glucose and insulin, and CRP levels; $p>0.05$ for all).

Table 1. Pre-treatment participants' characteristics.

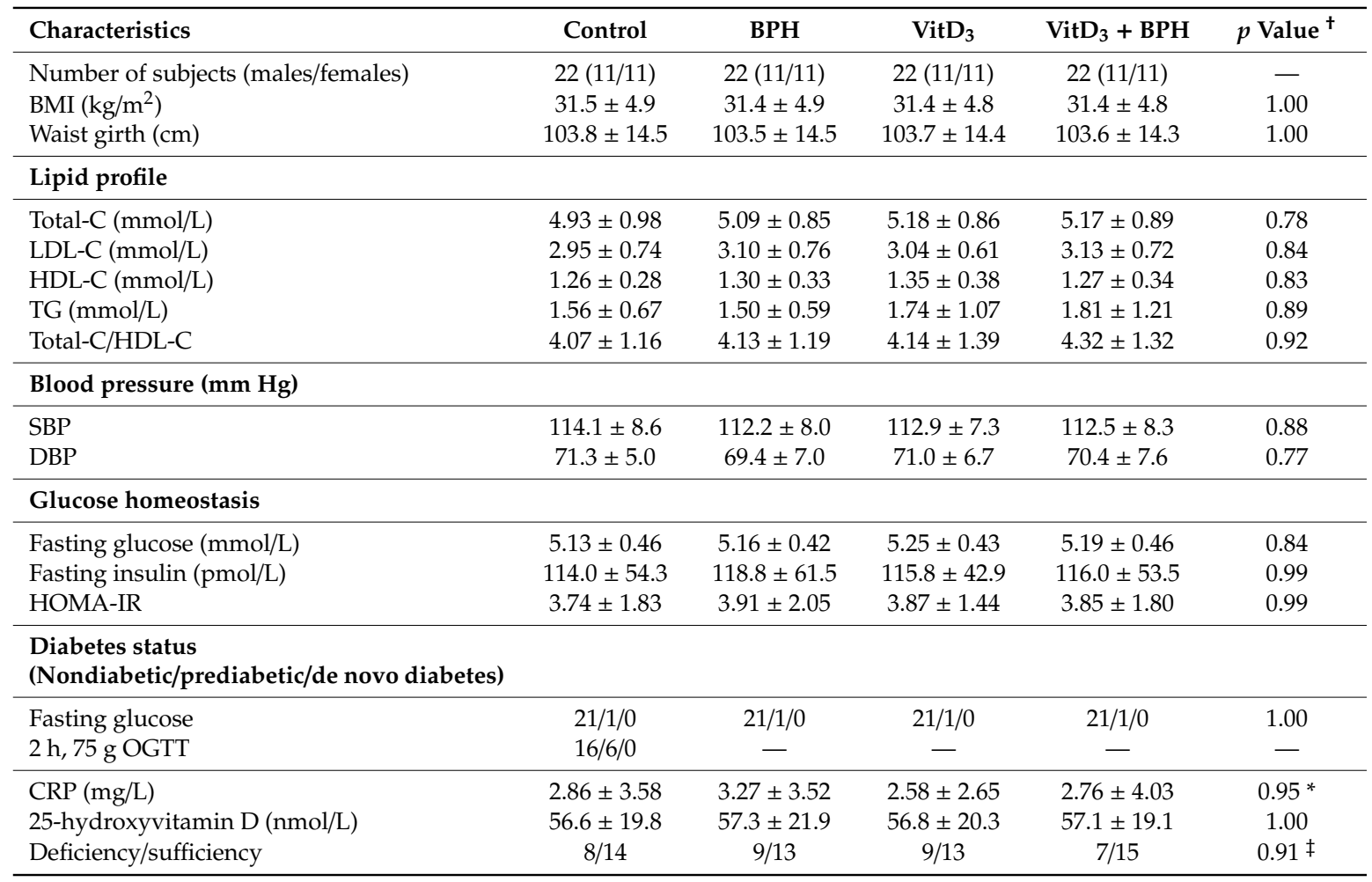

Values presented (means \pm SD) are untransformed and unadjusted values. Diabetes status defined according to fasting and $2 \mathrm{~h}$ post-oral glucose tolerance test (OGTT) glucose levels [39]. 25-hydroxyvitamin D (25(OH)D) deficiency defined as serum levels $<50 \mathrm{nmol} / \mathrm{L}(<20 \mathrm{ng} / \mathrm{mL}) .{ }^{*} p$ value obtained from $\log _{10}$-transformed values. ${ }^{\dagger} p$ value from analysis of variance (ANOVA) for between-group differences. ${ }^{\ddagger} p$ value obtained from $\mathrm{Chi}^{2}$ test. Abbreviations: $\mathrm{BPH}$, Bonito fish peptide hydrolysate treatment; $\mathrm{Vit}_{3}$, vitamin $\mathrm{D}_{3}$ treatment; $\mathrm{BMI}$, body mass index; Total-C, total cholesterol; LDL-C, low-density lipoprotein cholesterol; HDL-C, high-density lipoprotein cholesterol; TG, triglycerides; SBP, systolic blood pressure; DBP, diastolic blood pressure; OGTT, oral glucose tolerance test; CRP, C-reactive protein.

\subsection{Changes in Glucose, Insulin, C-Peptide, and TG during Post-Oral Glucose Tolerance Test (OGTT)}

There was no treatment-by-time interaction for glucose, insulin, C-Peptide, and TG levels. Differences between treatments at each time point were also tested. Moreover, no difference was identified between treatments at either of the time points (Table 2). Following adjustments for the effects of age and sex, there was no significant difference between groups in incremental areas under the curve (iAUC) for glucose $(p=0.97)$, insulin $(p=0.39)$, and C-Peptide $(p=0.36)$ levels, or in areas under the curve (AUC) for TG levels ( $p=0.91$; Supplementary Figure S1). 
Table 2. Effects of treatments on glucose, insulin, C-peptide and triglyceride during oral glucose tolerance test.

\begin{tabular}{|c|c|c|c|c|c|c|c|}
\hline Treatment Metabolic Parameter & 0 & 15 & 30 & 60 & 120 & 180 & $p$ Value $^{\dagger}$ \\
\hline \multicolumn{8}{|l|}{ Control } \\
\hline Glucose (mmol/L) & $5.13 \pm 0.46$ & $6.86 \pm 0.97$ & $7.99 \pm 1.60$ & $7.72 \pm 2.58$ & $6.14 \pm 1.64$ & $4.40 \pm 1.35$ & 0.98 \\
\hline Insulin (pmol/L) & $114.0 \pm 54.3$ & $524.0 \pm 286.5$ & $858.6 \pm 446.3$ & $977.5 \pm 502.9$ & $733.6 \pm 402.5$ & $286.5 \pm 258.7$ & 0.21 \\
\hline C-peptide (pmol/L) & $894.7 \pm 279.9$ & $2028.3 \pm 659.5$ & $3016.9 \pm 944.6$ & $3811.3 \pm 1047.0$ & $3624.4 \pm 1169.0$ & $2171.6 \pm 944.1$ & 0.41 \\
\hline $\mathrm{TG}(\mathrm{mmol} / \mathrm{L})$ & $1.43 \pm 0.67$ & $1.40 \pm 0.60$ & $1.47 \pm 0.63$ & $1.52 \pm 0.64$ & $1.41 \pm 0.67$ & $1.37 \pm 0.65$ & 0.54 \\
\hline \multicolumn{8}{|l|}{ ВPH } \\
\hline Glucose (mmol/L) & $5.16 \pm 0.42$ & $7.06 \pm 1.11$ & $8.08 \pm 1.79$ & $7.61 \pm 2.31$ & $6.51 \pm 1.87$ & $4.39 \pm 1.80$ & \\
\hline Insulin (pmol/L) & $118.8 \pm 61.5$ & $592.2 \pm 398.1$ & $1025.9 \pm 565.4$ & $1151.6 \pm 872.5$ & $947.8 \pm 506.2$ & $313.5 \pm 276.5$ & \\
\hline C-peptide (pmol/L) & $960.0 \pm 287.7$ & $2284.0 \pm 889.1$ & $3382.1 \pm 1091.7$ & $4163.0 \pm 1467.1$ & $4189.3 \pm 1163.2$ & $2487.0 \pm 1034.6$ & \\
\hline $\mathrm{TG}(\mathrm{mmol} / \mathrm{L})$ & $1.36 \pm 0.56$ & $1.38 \pm 0.56$ & $1.40 \pm 0.54$ & $1.42 \pm 0.57$ & $1.36 \pm 0.55$ & $1.36 \pm 0.56$ & \\
\hline \multicolumn{8}{|l|}{ VitD $_{3}$} \\
\hline Glucose (mmol/L) & $5.25 \pm 0.43$ & $7.00 \pm 0.94$ & $8.08 \pm 1.42$ & $8.03 \pm 2.67$ & $6.49 \pm 1.97$ & $4.41 \pm 1.61$ & \\
\hline Insulin (pmol/L) & $115.8 \pm 42.9$ & $562.0 \pm 309.1$ & $898.6 \pm 469.9$ & $1052.1 \pm 495.2$ & $914.6 \pm 527.0$ & $300.9 \pm 252.6$ & \\
\hline C-peptide (pmol/L) & $934.4 \pm 225.8$ & $2132.8 \pm 682.2$ & $3169.7 \pm 957.7$ & $4083.3 \pm 899.8$ & $4016.3 \pm 1448.1$ & $2282.7 \pm 1075.2$ & \\
\hline $\mathrm{TG}(\mathrm{mmol} / \mathrm{L})$ & $1.59 \pm 0.99$ & $1.58 \pm 0.98$ & $1.58 \pm 0.96$ & $1.59 \pm 0.94$ & $1.53 \pm 0.97$ & $1.54 \pm 0.99$ & \\
\hline \multicolumn{8}{|l|}{$\mathrm{VitD}_{3}+\mathrm{BPH}$} \\
\hline Glucose (mmol/L) & $5.19 \pm 0.46$ & $7.21 \pm 1.13$ & $7.90 \pm 1.65$ & $8.12 \pm 2.49$ & $6.42 \pm 1.78$ & $4.39 \pm 1.48$ & \\
\hline Insulin (pmol/L) & $116.0 \pm 53.5$ & $624.5 \pm 351.7$ & $889.6 \pm 595.9$ & $1114.2 \pm 772.1$ & $1035.7 \pm 508.3$ & $393.7 \pm 372.3$ & \\
\hline C-peptide (pmol/L) & $957.9 \pm 292.1$ & $2295.3 \pm 783.2$ & $3179.8 \pm 1071.9$ & $4177.2 \pm 1195.0$ & $4229.2 \pm 1106.9$ & $2478.3 \pm 1264.5$ & \\
\hline $\mathrm{TG}(\mathrm{mmol} / \mathrm{L})$ & $1.61 \pm 0.99$ & $1.62 \pm 0.97$ & $1.59 \pm 0.85$ & $1.60 \pm 0.83$ & $1.45 \pm 0.81$ & $1.46 \pm 0.69$ & \\
\hline Glucose $p$ value ${ }^{t+}$ & 0.81 & 0.71 & 0.98 & 0.88 & 0.89 & 1.00 & \\
\hline Insulin $p$ value ${ }^{+\dagger}$ & 0.99 & 0.78 & 0.70 & 0.84 & 0.23 & 0.63 & \\
\hline C-peptide $p$ value ${ }^{+\dagger}$ & 0.83 & 0.58 & 0.68 & 0.71 & 0.35 & 0.70 & \\
\hline TG $p$ value t+ $^{++}$ & 0.69 & 0.72 & 0.80 & 0.84 & 0.90 & 0.82 & \\
\hline
\end{tabular}

Values presented (means $\pm \mathrm{SD}$ ) are untransformed and unadjusted values. Vitamin D deficiency defined as serum levels $<50 \mathrm{nmol} / \mathrm{L}(<20 \mathrm{ng} / \mathrm{mL}){ }^{\dagger} p$ value for time $\mathrm{x}$ treatment interaction

with adjustment for age, sex, and serum 25-hydroxyvitamin D concentrations. ${ }^{\text {tt }} p$ values for between-treatment differences at each timepoint obtained from the analysis of variance

(ANOVA) and adjusted for the effects of age and sex. Abbreviations: BPH, Bonito fish peptide hydrolysate treatment: Vit $\mathrm{D}_{3}$, vitamin $\mathrm{D}_{3}$ treatment; $\mathrm{TG}$, triglycerides. 


\subsection{Gene Expression Analysis}

Eighteen participants aged 24 to 68 years (mean $49.7 \pm 13.7$ years) were selected for further gene expression analyses. This subset composed of 10 men and 8 post-menopausal women (Table 3), did not significantly differ from the full cohort at baseline for metabolic parameters $(p>0.05$ for all; Supplementary Table S1). Furthermore, the characteristics of the gene expression cohort did not differ between treatments at baseline. Whole-genome expression levels were measured before and 180 min post-ingestion for each treatment (placebo control, $\mathrm{BPH}, \mathrm{VitD}_{3}, \mathrm{VitD}_{3}+\mathrm{BPH}$ ). Following adjustments for age, sex, BMI, and estimated blood cell count, slight differences in gene expression levels were identified for the control treatment; three transcripts (NM_002612 (pyruvate dehydrogenase kinase 4, PDK4), NM_001145775 (FKBP prolyl isomerase 5, FKBP5), NM_001015881 (TSC22 domain family member 3, TSC22D3)) being found differentially expressed (false discovery rate (FDR)-adjusted $p$ value $\leq 0.05)$. These transcripts were removed from differential methylation analyses for the $\mathrm{BPH}, \mathrm{Vit}_{3}$, and $\mathrm{VitD}_{3}+\mathrm{BPH}$ treatments. Despite the fact that similar global expression levels were found (Figure 1 ), $\mathrm{VitD}_{3}$ treatment differentially affected 16 transcripts while $\mathrm{BPH}$ and $\mathrm{VitD}_{3}+\mathrm{BPH}$ treatments were found to differentially change 1 and 5 transcripts, respectively (Table 4, Figure 1 and Supplementary Table S2). Among these, some transcripts were found to be differentially expressed by more than one treatment (Figure 2). A transcript for the carnitine palmitoyltransferase 1A (CPT1A) gene was found differentially expressed with $\mathrm{VitD}_{3}, \mathrm{BPH}$, and $\mathrm{VitD}_{3}+\mathrm{BPH}$ treatments. $\mathrm{VitD}_{3}$-containing treatments, with or without $\mathrm{BPH}$, affected transcript of the solute carrier family 25 member 20 (SLC25A20) gene. Both genes are known to encode proteins involved in fatty acids $\beta$-oxidation. The NM_001285829 transcript, encoding the CCAAT enhancer binding protein alpha (CEBPA) transcription factor involved in cell cycle regulation and body weight homeostasis, was also found to be differentially expressed by $\mathrm{VitD}_{3}$ treatment.

Table 3. Pre-treatment characteristics for the gene expression cohort.

\begin{tabular}{|c|c|c|c|c|c|}
\hline Characteristics & Control & ВРH & $\mathrm{VitD}_{3}$ & $\mathrm{VitD}_{3}+\mathrm{BPH}$ & $p$ Value $^{\dagger}$ \\
\hline Number of subjects (males/females) & $18(10 / 8)$ & $18(10 / 8)$ & $18(10 / 8)$ & $18(10 / 8)$ & - \\
\hline BMI $\left(\mathrm{kg} / \mathrm{m}^{2}\right)$ & $31.4 \pm 4.9$ & $31.3 \pm 4.9$ & $31.3 \pm 4.9$ & $31.3 \pm 4.8$ & 1.00 \\
\hline Waist girth (cm) & $105.7 \pm 14.9$ & $105.3 \pm 15.0$ & $105.6 \pm 14.9$ & $105.5 \pm 14.8$ & 1.00 \\
\hline \multicolumn{6}{|l|}{ Lipid profile } \\
\hline Total-C (mmol/L) & $4.90 \pm 0.95$ & $5.14 \pm 0.89$ & $5.25 \pm 0.89$ & $5.18 \pm 0.94$ & 0.68 \\
\hline LDL-C (mmol/L) & $2.95 \pm 0.68$ & $3.17 \pm 0.77$ & $3.15 \pm 0.58$ & $3.18 \pm 0.72$ & 0.70 \\
\hline HDL-C (mmol/L) & $1.23 \pm 0.25$ & $1.26 \pm 0.27$ & $1.33 \pm 0.35$ & $1.27 \pm 0.29$ & 0.76 \\
\hline $\mathrm{TG}(\mathrm{mmol} / \mathrm{L})$ & $1.56 \pm 0.70$ & $1.54 \pm 0.62$ & $1.66 \pm 1.06$ & $1.59 \pm 0.82$ & 0.98 \\
\hline Total-C/HDL-C & $4.09 \pm 1.05$ & $4.24 \pm 1.14$ & $4.18 \pm 1.38$ & $4.24 \pm 1.12$ & 0.98 \\
\hline \multicolumn{6}{|l|}{ Blood pressure (mm Hg) } \\
\hline SBP & $115.5 \pm 8.7$ & $113.2 \pm 8.2$ & $114.6 \pm 6.9$ & $113.6 \pm 8.6$ & 0.83 \\
\hline DBP & $70.9 \pm 4.9$ & $68.5 \pm 7.1$ & $70.7 \pm 7.1$ & $69.1 \pm 7.2$ & 0.64 \\
\hline \multicolumn{6}{|l|}{ Glucose homeostasis } \\
\hline Fasting glucose (mmol/L) & $5.18 \pm 0.45$ & $5.22 \pm 0.43$ & $5.29 \pm 0.42$ & $5.24 \pm 0.48$ & 0.91 \\
\hline Fasting insulin (pmol/L) & $110.9 \pm 58.6$ & $111.0 \pm 64.1$ & $113.3 \pm 45.0$ & $108.8 \pm 55.2$ & 1.00 \\
\hline HOMA-IR & $3.71 \pm 2.02$ & $3.73 \pm 2.20$ & $3.82 \pm 1.49$ & $3.67 \pm 1.91$ & 1.00 \\
\hline \multicolumn{6}{|c|}{$\begin{array}{l}\text { Diabetes status } \\
\text { (Nondiabetic/prediabetic/de novo diabetes) }\end{array}$} \\
\hline Fasting glucose & $18 / 1 / 0$ & $18 / 1 / 0$ & $18 / 1 / 0$ & $18 / 1 / 0$ & 1.00 \\
\hline $2 \mathrm{~h}, 75 \mathrm{~g}$ OGTT & $13 / 6 / 0$ & - & - & - & - \\
\hline $\mathrm{CRP}(\mathrm{mg} / \mathrm{L})$ & $3.16 \pm 3.99$ & $3.14 \pm 3.42$ & $2.71 \pm 2.92$ & $2.98 \pm 4.40$ & $0.97 *$ \\
\hline 25-hydroxyvitamin D (nmol/L) & $61.0 \pm 18.5$ & $62.2 \pm 20.3$ & $61.4 \pm 18.6$ & $61.8 \pm 17.0$ & 0.98 \\
\hline Deficiency/sufficiency & $5 / 13$ & $6 / 12$ & $6 / 12$ & $4 / 14$ & $0.74^{\ddagger}$ \\
\hline
\end{tabular}

Values presented (means \pm SD) are untransformed and unadjusted values. Diabetes status defined according to fasting and $2 \mathrm{~h}$ post-OGTT glucose levels [39]. 25(OH)D deficiency defined as serum levels $<50 \mathrm{nmol} / \mathrm{L}$ $(<20 \mathrm{ng} / \mathrm{mL}) .{ }^{+} p$ value from analysis of variance (ANOVA) for between-group differences. ${ }^{*} p$ value obtained from $\log _{10}$-transformed values. $\ddagger$ emphp value obtained from $\mathrm{Chi}^{2}$ test. Abbreviations: BPH, Bonito fish peptide hydrolysate treatment: $\mathrm{VitD}_{3}$, vitamin $\mathrm{D}_{3}$ treatment; $\mathrm{BMI}$, body mass index; Total-C, total cholesterol; LDL-C; low-density lipoprotein cholesterol; HDL-C, high-density lipoprotein cholesterol; TG, triglycerides; SBP, systolic blood pressure; DBP, diastolic blood pressure; CRP, C-reactive protein. 
(a)

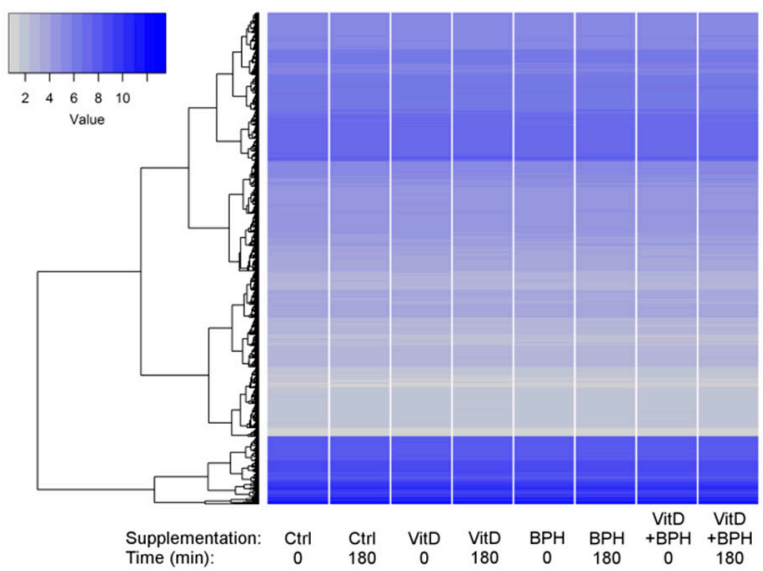

(b)

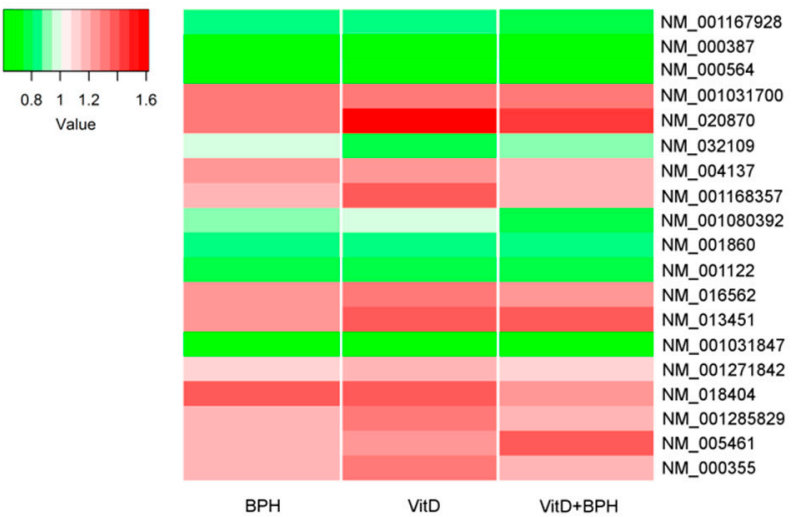

Figure 1. Heat maps of probe expression levels. (a) Heat map and hierarchical clustering of mean transcript expression levels before (Time $=0)$ and $3 \mathrm{~h}$ after (Time $=180)$ each treatment $(24351$ expression probes). (b) Heat map depicting fold changes in expression levels after vs. before treatment for differentially expressed probes (false discovery rate (FDR)-adjusted $p$ value $\leq 0.05$ ).

Table 4. Differentially expressed transcripts for the $\mathrm{BPH}, \mathrm{VitD}_{3}$ and $\mathrm{VitD}_{3}+\mathrm{BPH}$ treatments.

\begin{tabular}{|c|c|c|c|c|c|}
\hline Transcript & Gene Symbol & Probe ID & Treatment & Fold Change & FDR $p$ Value \\
\hline NM_001031847 & СРТ1A & TC1100011395.hg.1 & $\mathrm{VitD}_{3}$ & 0.67 & $2.6 \times 10^{-6}$ \\
\hline NM_001031847 & CPT1A & TC1100011395.hg.1 & $\mathrm{BPH}$ & 0.67 & 0.0005 \\
\hline NM_001031847 & CPT1A & TC1100011395.hg.1 & $\mathrm{VitD}_{3}+\mathrm{BPH}$ & 0.60 & 0.002 \\
\hline NM_000387 & SLC25A20 & TC0300011038.hg.1 & $\mathrm{VitD}_{3}+\mathrm{BPH}$ & 0.61 & 0.0002 \\
\hline NM_000387 & SLC25A20 & TC0300011038.hg.1 & $\mathrm{VitD}_{3}$ & 0.63 & 0.009 \\
\hline NM_001167928 & IL1RAP & TC0300009855.hg.1 & $\mathrm{VitD}_{3}+\mathrm{BPH}$ & 0.78 & 0.04 \\
\hline NM_001080392 & KIAA1147 & TC0700012836.hg.1 & $\mathrm{VitD}_{3}+\mathrm{BPH}$ & 0.81 & 0.04 \\
\hline NM_005461 & $M A F B$ & TC2000009116.hg.1 & $\mathrm{VitD}_{3}+\mathrm{BPH}$ & 1.40 & 0.04 \\
\hline NM_020870 & SH3RF1 & TC0400012378.hg.1 & $\mathrm{VitD}_{3}$ & 1.62 & 0.008 \\
\hline NM_001031700 & FAM198B & TC0400012245.hg.1 & $\mathrm{VitD}_{3}$ & 1.34 & 0.008 \\
\hline NM_018404 & $A D A P 2$ & TC1700012226.hg.1 & $\mathrm{VitD}_{3}$ & 1.37 & 0.008 \\
\hline NM_000564 & $I L 5 R A$ & TC0300013923.hg.1 & $\mathrm{VitD}_{3}$ & 0.74 & 0.008 \\
\hline NM_001285829 & CEBPA & TC1900010386.hg.1 & $\mathrm{VitD}_{3}$ & 1.34 & 0.009 \\
\hline NM_001860 & SLC31A2 & TC0900008482.hg.1 & $\mathrm{VitD}_{3}$ & 0.84 & 0.02 \\
\hline NM_001271842 & SCIMP & TC1700009556.hg.1 & $\mathrm{VitD}_{3}$ & 1.20 & 0.02 \\
\hline NM_016562 & TLR7 & TC0X00006625.hg.1 & $\mathrm{VitD}_{3}$ & 1.30 & 0.03 \\
\hline NM_013451 & MYOF & TC1000011445.hg.1 & $\mathrm{VitD}_{3}$ & 1.40 & 0.03 \\
\hline NM_004137 & KCNMB1 & TC0500012791.hg.1 & $\mathrm{VitD}_{3}$ & 1.24 & 0.03 \\
\hline
\end{tabular}


Table 4. Cont.

\begin{tabular}{lllccc}
\hline Transcript & Gene Symbol & Probe ID & Treatment & Fold Change & FDR $\boldsymbol{p}$ Value \\
\hline NM_001168357 & PLA2G7 & TC0600011953.hg.1 & VitD $_{3}$ & 1.39 & 0.04 \\
NM_032109 & OTP & TC0500011211.hg.1 & VitD $_{3}$ & 0.79 & 0.04 \\
NM_001122 & PLIN2 & TC0900012212.hg.1 & VitD $_{3}$ & 0.76 & 0.04 \\
NM_000355 & TCN & TC2200009257.hg.1 & VitD $_{3}$ & 1.30 & 0.04 \\
\hline
\end{tabular}

List of differentially expressed transcripts (time $=180 \mathrm{vs}$. time $=0$ ) according to treatments. Transcripts differentially expressed in more than one treatment are shown at the top of the table and separated by dotted lines. Abbreviations: FDR $p$ value, False discovery rate-adjusted $p$ value; $\mathrm{BPH}$, Bonito fish peptide hydrolysate treatment; $\mathrm{Vit}_{3}$, vitamin $\mathrm{D}_{3}$ treatment.

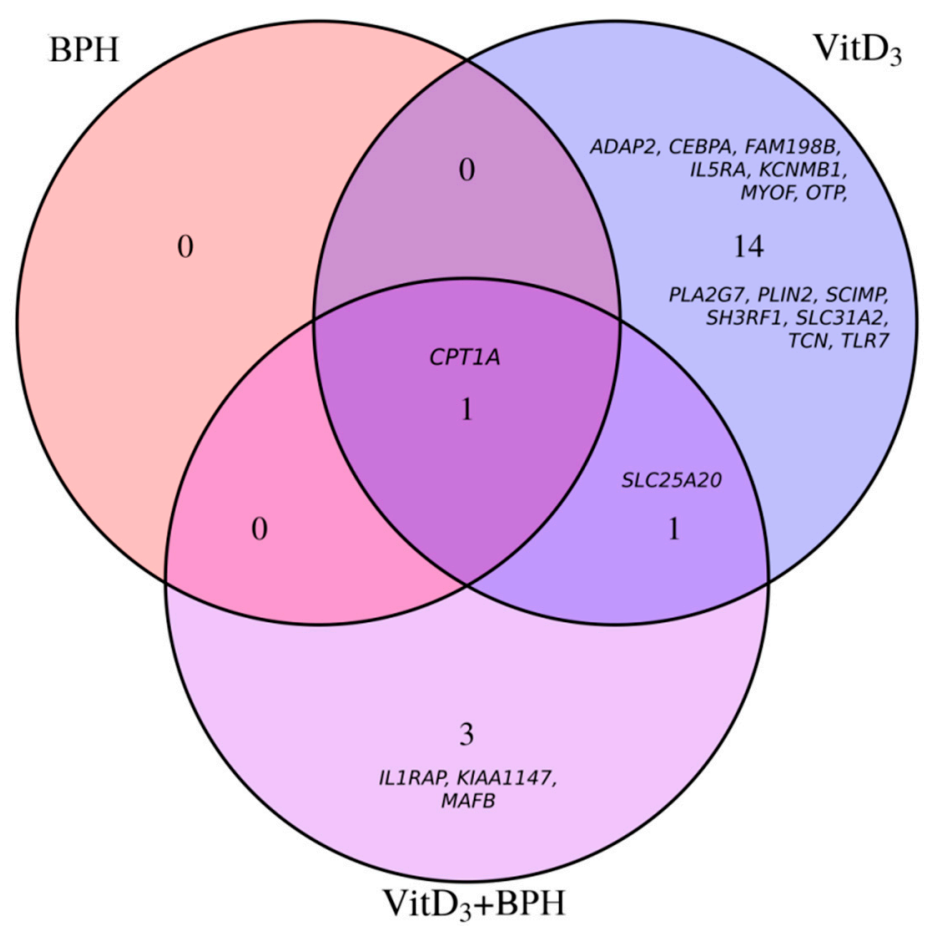

Figure 2. Venn diagram of treatment-regulated genes. Venn diagram showing the overlap of differentially expressed transcripts for the bonito fish peptide hydrolysate $(B P H)$, vitamin $\mathrm{D}_{3}\left(\operatorname{VitD}_{3}\right)$ and the vitamin $D_{3}+$ bonito fish peptide hydrolysate $\left(\mathrm{Vit}_{3}+\mathrm{BPH}\right)$ treatments. Number of differentially expressed transcripts and gene symbols are provided.

The list of differentially expressed transcripts following $\mathrm{Vit}_{3}$ treatment was submitted for gene function and pathway analysis. The top two most significant overrepresented functions were Lipid metabolism and Molecular transport functions (Supplementary Table S3). Differentially expressed transcripts encoding SLP adaptor and CSK interacting membrane protein (SCIMP), CPT1, phospholipase A2 group VII (PLA2G7), perilipin 2 (PLIN2) and CEBPA proteins were common to these functions. In addition, three pathways (Mitochondrial L-carnitine Shuttle; Role of Macrophages, Fibroblasts and Endothelial Cells in Rheumatoid Arthritis; Unfolded protein response) were found overrepresented among differentially expressed transcripts following $\mathrm{Vit}_{3}$ treatment.

\section{Discussion}

In the current study, we used a cohort of metabolically deteriorated men and women to assess the effects of $\mathrm{BPH}, \mathrm{VitD}_{3}$, and $\mathrm{VitD}_{3}+\mathrm{BPH}$ treatments at the metabolic and gene expression levels. While the study was not specifically designed to include $25(\mathrm{OH}) \mathrm{D}$-deficient individuals, the cohort included about one-third of subjects with $25(\mathrm{OH}) \mathrm{D}$ deficiency, which is similar to the prevalence reported in Canada during fall/winter where most of our recruitment took place. Our study differs from most supplementation studies as it did not aim at evaluating the long-term effects of fish peptides and/or 
$\mathrm{Vit}_{3}$ on CVD risk factors. It specifically focused on acute effects of treatments at the gene expression level. It was designed to investigate the effects of low-dose acute exposition to $\mathrm{BPH}$ and/or $\mathrm{VitD}_{3}$ in overweight or obese participants rather than to study the effects of restoring sufficiency in $25(\mathrm{OH}) \mathrm{D}$ levels in severely metabolically compromised individuals. The latter study design may increase the number of differentially expressed transcripts in comparison to numbers identified in the present study.

We conducted a randomized, crossover, placebo controlled trial in which each participant followed all treatments and the placebo treatment. While this study design minimized confounding factors, we did not observe an acute effect of $1000 \mathrm{IU}$ of $\mathrm{VitD}_{3}, 3 \mathrm{~g}$ of $\mathrm{BPH}$ or $\mathrm{VitD}_{3}+\mathrm{BPH}$ treatments on glucose homeostasis (glucose, insulin, and C-Peptide). Although the effect of BPH on glucose homeostasis and lipid profile were not studied in RCT, discordant results were observed regarding the benefits of $\mathrm{VitD}_{3}$ supplementation on glucose homeostasis [31-33]. A long-term study that tested the impact of 8-week $\mathrm{VitD}_{3}$ supplementation (50,000 IU weekly) on TG levels in 25(OH)D deficient individuals [29] did not report improvements in lipid profile similarly to results obtained in the current acute study. In contrast, these results are discordant with those of a recent 8-week RCT reporting increased blood lipid concentrations following high-dose $\mathrm{VitD}_{3}$ (2800 IU daily) supplementation in hypertensive, middle-aged patients with low 25(OH)D levels [40]. Focusing on patients with T2D, a meta-analysis of RCT identified lowering effects of $\mathrm{Vit}_{3}$ on Total-C and LDL-C, without significant changes in TG levels [41]. Such discrepancies between results from the above-mentioned studies may be explained by the metabolic state of the study participants, the dose administered or the duration of treatment. Moreover, $25(\mathrm{OH}) \mathrm{D}$ was shown to act on a variety of different mechanisms in addition to regulating the transcription of target genes through modulation of the activity of the vitamin D receptor [42], potentially contributing to the explanation of these discrepancies.

Specifically investigating changes in gene expression levels following acute treatment with BPH and $\mathrm{VitD}_{3}$, the current study was designed to explore potentially new mechanisms underlying the acute impact of such treatments. Following the removal of differentially expressed transcripts found in the placebo treatment, overlap was identified among differentially expressed transcripts from the three treatments. A decrease in CPT1A gene expression level was observed for all three active treatments while SLC25A20 showed statistically significant reduction in gene expression levels under VitD ${ }_{3}$-containing $\left(\mathrm{VitD}_{3}\right.$ and $\left.\mathrm{VitD}_{3}+\mathrm{BPH}\right)$ treatments. The CPT1A gene encodes a carnitine-dependent transporter involved in mitochondrial oxidation of long-chain fatty acids. It is one of the rate-limiting steps in fatty acid $\beta$-oxidation [43]. Following translocation of fatty acids through the plasma membrane, they are activated by reaction with $\mathrm{CoA}$ to form acyl-CoAs and thereafter, converted to acylcarnitines by mitochondrial membrane CPT1 (encoded by the CPT1A gene in several tissues). Acylcarnitines are then translocated into the mitochondria by solute carrier family 25 member 20 (SLC25A20), formerly termed carnitine acylcarnitine translocase (CACT). Following reconversion of acylcarnitines into acyl-CoAs, they are processed to further undergo fatty acid $\beta$-oxidation [44], thus, resulting in energy production. These two genes, herein showing reduced levels in the blood following treatment, were found among the top increased genes in the peripheral blood mononuclear cells transcriptome of diet-induced obese rats $[45,46]$, concordant with the reported inverse association between serum $25(\mathrm{OH}) \mathrm{D}$, weight, and fat mass [47]. Results from the current study are in accordance with results from a recent 12-week RCT (2000 IU daily) in obese subjects demonstrating an enrichment of genes related to mitochondrial function among $\mathrm{Vit}_{3}$ regulated genes. On the opposite, reduced expression of genes participating in fatty acid $\beta$-oxidation would potentially result in lower fatty acid $\beta$-oxidation and triacylglycerol accumulation, which is concordant with results from RCT $[40,41]$, thus, adding to discrepancies on the potential mechanisms linking 25(OH)D and cardiovascular health [34]. In view of above-mentioned mechanisms and in combination to results from function and pathway analyses showing overrepresentation of Lipid metabolism and Molecular transport functions, our gene expression results argue for a metabolic impact of $25(\mathrm{OH}) \mathrm{D}$ possibly through modification of lipid metabolism. Changes identified here may be acutely driven, tissue-specific or dose-dependent. Based on the short-term effects of $\mathrm{VitD}_{3}$ herein identified, it is tempting to speculate that these effects may be mediated through membrane-based 
signaling rather than through vitamin D receptor signaling [42]. Specifically assessing short-term effects of a single dose of $\mathrm{Vit}_{3}$ may potentially limit the effects of the treatment through long-term mechanisms of action, and explain the low number of differentially expressed transcripts identified in comparisons to long term supplementation studies [36]. The low-dose, acute exposition to $\mathrm{VitD}_{3}$ also limits changes induced by the treatment. An important reduced number of significantly regulated genes was observed in the present study in comparison to the $>700$ genes reported in peripheral blood mononuclear cells, with expression levels measured $24 \mathrm{~h}$ after an 80,000 IU (2000 $\mu \mathrm{g}) \mathrm{VitD}_{3}$ bolus in five participants [48]. The opposite effects of high dose $\mathrm{Vit}_{3}$ were recently reported in differentiated adipocytes with increased CPT1A gene expression, stimulated fatty acid oxidation, and reduced triacylglycerol accumulation [49].

The effect of $\mathrm{VitD}_{3}$ supplementation on glucose metabolism remains controversial, some studies reporting a reduction in glycemic markers and others reporting the opposite effects [7,50]. Nevertheless, $25(\mathrm{OH}) \mathrm{D}$ is thought to play a role in glycemic control through different mechanisms. It was shown to modulate insulin synthesis in pancreatic beta cells and to influence insulin sensitivity [51-53]. The current analysis identified overexpression of the CEBPA gene encoding a transcription factor (TF) belonging to the CCAAT/enhancer binding proteins (CEBP) family. This TF plays an important regulatory role in glucose metabolism, cell cycle, hematopoiesis, skeletal development, immune response, and adipocyte differentiation [54]. Based on the regulatory role of CEBPA in glucose metabolism, it could be hypothesized that the relationship between $25(\mathrm{OH}) \mathrm{D}$ and the glucose metabolic variables reported in RCT [31,32] may be modulated through regulation of TF and downstream targets acting on target tissues [50].

The beneficial effects of fish consumption regarding CVD mortality in regular fish consumers may be attributable to several nutrients and not only to omega-3 polyunsaturated fatty acids. Our study investigating the acute effects of fish nutrients indicate rapid onset modulation of some genes related to lipid and glucose metabolism by $\mathrm{Vit}_{3}$ treatment. Acute $\mathrm{BPH}$ treatment only slightly modulated gene expression levels in blood. Longer exposure is likely necessary to exert genomic effects. In conclusion, the present study at gene expression level shows acute modulation of lipid and glucose metabolism following $\mathrm{VitD}_{3}$ treatment in line with protective long-term effects reported in observational studies.

\section{Materials and Methods}

\subsection{Study Participants}

Individuals from the greater Quebec City metropolitan area were recruited through advertisements in local newspapers and by electronic messages sent to university students/employees. Subjects were recruited from September 2015 to May 2016. This study evaluated the effects of a short-term treatment on cardiometabolic risk markers, and included 11 men and 11 women (2 pre-menopausal and 9 post-menopausal) aged between 18 and 65 years old. Participants had to be overweight or obese (BMI ranging from 25 to $40 \mathrm{~kg} / \mathrm{m}^{2}$ ) and free of any metabolic disorders requiring treatment. Individuals were excluded if they were using medications affecting glucose or vitamin D metabolism or plasma lipid levels. Volunteers who had been taking supplements in the last 3 months were excluded. Subjects were also excluded if they had fish/seafood taste aversion or allergy, were regular alcohol drinkers ( $>2$ drinks/d), had lost $>5 \%$ weight over the last 3 months, had major surgery in the 3 months prior to study onset. Among the 39 subjects screened, 24 were eligible; one chose not to participate before the beginning of the study while another withdrawn during the study for personal reasons, thus, resulting in 22 participants at the end of the study including 6 smokers.

Waist girth, resting SBP and DBP were measured using standardized procedures [55]. BMI was calculated as weight in kilograms divided by height in square meters. This study was conducted in accordance with the Declaration of Helsinki and approved by the Universite Laval Ethics Committee (approval number 2015-090; approved on 1 July 2015). All participants provided written informed consent, and the trial was registered before study commencement at clinicaltrials.gov as NCT02668159. 


\subsection{Study Design}

A randomized, crossover, placebo controlled trial was conducted. This study consisted of 5 visits to the Institute of Nutrition and Functional Food (INAF) clinical investigation unit. The first visit was a screening visit. Participants filled in questionnaires about socio-demographic characteristics, medical history, and lifestyle habits as well as physical activity [56]. A questionnaire documenting sun exposure in weekdays, weekends, and last vacations, as well as the use of tanning beds and sunscreen was administered. A validated food frequency questionnaire [57], documenting diet for the last month, including fish, seafood, and alcohol consumption, was administered at the first treatment visit by a registered dietitian. A medical follow-up form was completed at each visit to document changes in medical condition and medication during the study. Subjects were asked to follow the same eating habits and physical activity throughout the study, and to limit their alcohol consumption during the protocol. Two regular drinks per week were allowed, but alcohol abstinence was required $48 \mathrm{~h}$ before study visits. In addition, subjects were not allowed to take omega-3, $\mathrm{VitD}_{3}$, multivitamin or protein supplements during the study. They were also asked to avoid any natural health or omega-3 enriched products, and to limit fish and seafood consumption to 2 servings per week during the protocol. Subjects were asked to report any deviation during the protocol.

\subsection{VitD $D_{3}$ and $B P H$ Treatment}

Following the screening visit, participants were randomized to a treatment sequence composed of placebo, $\mathrm{BPH}, \mathrm{VitD}_{3}$, and $\mathrm{VitD}_{3}+\mathrm{BPH}$ treatment in random order using single randomization generator implemented in INAF online platform for managing nutritional clinical studies. Participants ingested, in random order and at 7-day intervals, $1000 \mathrm{IU}(25 \mu \mathrm{g})$ of $\mathrm{VitD}_{3}$ (cholecalciferol; Santé Naturelle A.G. Ltée, Brossard, QC, Canada), 3 g of BPH (PeptACE ${ }^{\circledR}$, Natural Factors Nutritional Products Limited, Coquitlam, BC, Canada), a combination of both, or a placebo. Study capsules were coded by a third party. A registered dietitian randomized the treatments and observed the consumption of the capsules by the participants. Participants were blinded to the treatment. All treatments consisted of 7 capsules, thus, resulting in similar-looking treatments despite slight differences for the BPH capsules. Participants, thus, consumed either a placebo (7 capsules of lactose), fish peptides (6 PeptACE ${ }^{\circledR}$ Fish Peptides capsules +1 lactose capsule), $\mathrm{VitD}_{3}\left(1 \mathrm{VitD}_{3}\right.$ capsule +6 lactose capsules), a combination of fish peptides and $\mathrm{VitD}_{3}\left(6\right.$ PeptACE ${ }^{\circledR}$ capsules $+1 \mathrm{VitD}_{3}$ capsule) right before an OGTT.

\subsection{Blood Sampling and Biochemical Measures}

A research nurse collected blood samples from an antecubital vein into vacutainer tubes containing ethylenediaminetetraacetic acid following a 12-h overnight fast and 48-h alcohol abstinence. Blood samples were collected during screening (visit 1) to identify and exclude individuals with any metabolic disorder as well as prior to each treatment (visits 2-5). Plasma samples were immediately processed after blood collection, aliquoted, and stored at $-80^{\circ} \mathrm{C}$. Plasma lipids (Total-C, LDL-C, HDL-C, and TG), as well as fasting plasma glucose and insulin concentrations, were measured using standardized procedures. Plasma CRP was measured by nephelometry (Prospec equipment, Behring, Siemens Healthcare Diagnosis, Deerfield, IL, USA) using a sensitive assay [58]. Fasting plasma insulin and glucose were measured by radioimmunoassay with polyethylene glycol separation, and enzymatically measured, respectively. Serum $25(\mathrm{OH}) \mathrm{D}$ (25-hydroxyvitamin D) levels were measured by electrochemiluminescence (Cobas System, Roche, Laval, QC, Canada) before each treatment. A 180-min OGTT (75 g of glucose) was performed following each treatment. Blood samples were collected into vacutainer tubes containing EDTA at $0,15,30,60,120$, and $180 \mathrm{~min}$, and glucose, insulin, C-peptide were measured. TG levels during an OGTT, being reported to be higher in insulin-resistant obese individuals and associated with metabolic risk, were also monitored throughout OGTT [59]. 


\subsection{Gene Expression Analysis}

A subset of 18 participants representative of the full cohort was selected for gene expression analyses. More precisely, this subset was selected to exclude pre-menopausal women to avoid the confounding effect of fluctuations in estrogen levels on serum 25(OH)D levels [60]. Blood samples were collected from an antecubital vein into PAXgene Blood RNA Tubes (Qiagen, Mississauga, ON, Canada) before and $180 \mathrm{~min}$ after each treatment. Total RNA was isolated and purified from blood samples using PAXgene Blood RNA Kit (Qiagen, Valencia, CA, USA)) according to the manufacturer's instructions. Quality and integrity of the purified RNA were assessed using both the NanoDrop (Thermo Scientific, Wilmington, DE, USA) and the 2100 Bioanalyzer (Agilent Technologies, Cedar Creek, TX, USA). Among the 144 RNA samples extracted (18 individuals, 4 treatments, 2 times), three samples did not meet quality criterion and were excluded from expression analyses. Expression levels were measured using the Affymetrix Clariom S HT (Thermo Fisher Scientific Inc., Waltham, MA, USA) and processed at the McGill University and Genome Quebec Innovation Centre (Montreal, QC, Canada). Arrays were scanned on an Agilent GeneArray Scanner (Thermo Fisher Scientific Inc.), and raw data were extracted from scanned images (CEL files) using Expression Console (v 1.4; Thermo Fisher Scientific Inc.). Expression Console was used to analyze image data and perform quality control. The Robust Multiarray Analysis method was used to perform background correction and quantile normalization. The Transcriptome Analysis Console Software (v2.0; Thermo Fisher Scientific Inc.) was used to extract normalized gene expression data from $\mathrm{CHP}$ files. Data reported in this paper have been deposited in the Gene Expression Omnibus (GEO) database, www.ncbi.nlm.nih.gov/geo (accession number GSE129604). Whole-genome expression levels were, thus, measured before and $180 \mathrm{~min}$ post-ingestion for each treatment (Placebo control (17 before, 18 at $180 \mathrm{~min}$ ), BPH (18 before and at 180 $\mathrm{min}), \mathrm{VitD}_{3}$ (17 before, 18 at $180 \mathrm{~min}$ ), $\mathrm{VitD}_{3}+\mathrm{BPH}$ (18 before, 17 at $\left.180 \mathrm{~min}\right)$ ). Following background correction and quantile normalization, blood cell proportions were predicted for each sample based on gene expression levels using the CellMix package (v1.6) [61]. Estimated cell counts were obtained and grouped in three classes: lymphocytes, neutrophils, and monocytes. Transcript levels were, thereafter, corrected for age, sex, BMI, serum 25(OH)D levels and estimated blood cell count. A moderated paired $t$-test on residuals was computed to test differences in expression levels after versus before treatment using the linear modeling approach and empirical Bayes statistics implemented in the limma software (v3.37.1) [62]. Changes observed in placebo (after vs. before treatment), possibly induced by venipuncture or OGTT, were systematically excluded from results obtained with other treatments.

Analysis of functions and pathways enriched from the list of differentially expressed genes following $\mathrm{VitD}_{3}$ treatment was conducted using the knowledge base of the Ingenuity Pathway Analysis system ${ }^{\circledR}$ (Ingenuity Systems, Redwood City, CA, USA).

\subsection{Statistics}

Clinical data before each treatment were expressed as mean \pm standard deviation. Group differences at baseline and at each time of the OGTT were tested using analysis of variance (general linear model). Comparisons among groups were performed using Duncan's multiple range test when differences were identified. Treatment-by-time interaction effects on dependent variables were assessed by using MIXED procedures for repeated measurements. Difference in 25(OH)D deficiency $(25(\mathrm{OH}) \mathrm{D}$ $<20 \mathrm{ng} / \mathrm{mL} ;<50 \mathrm{nmol} / \mathrm{L}$ ) [26] between each treatment phases were tested using Chi-squared test. AUC (TG) and the iAUC (glucose, insulin, and C-peptide) were calculated for the $180 \mathrm{~min}$ OGTT interval using the trapezoidal method. Statistical analyses on clinical data were performed using SAS statistical package version 9.4 (SAS Institute Inc., Cary, NC, USA).

Supplementary Materials: Supplementary materials can be found at http:/www.mdpi.com/1422-0067/20/8/1944/s1. Figure S1. Histograms of areas under the curve (AUC; white) and incremental AUC (iAUC; grey) for the 180 min OGTT interval. AUC and iAUC calculated from 21 participants due to missing data for a participant at 15 min under control treatment. iAUC for glucose (upper left), insulin (upper right), C-peptide (lower left) and AUC for triglyceride levels (lower right) are shown. Abbreviations: Ctrl, control treatment; BPH, Bonito fish peptide 
hydrolysate treatment: VitD, vitamin $\mathrm{D}_{3}$ treatment. Table S1. Differences in metabolic parameters between the expression subset and the full cohort. Table S2. Gene expression analysis for transcripts showing differential gene expression in at least one treatment. Table S3. Biological functions identified from the list of differentially expressed transcripts following $\mathrm{Vit}_{3}$ treatment.

Author Contributions: Conceptualization, H.J., C.G., A.M. and M.-C.V.; methodology, F.G., H.J., C.G., A.M. and M.-C.V.; formal analysis, F.G.; investigation, F.G.; resources, M.-C.V.; data curation, F.G.; writing-original draft preparation, F.G. and M.-C.V.; writing-review and editing, F.G., H.J., C.G., A.M. and M.-C.V.; visualization, F.G.; supervision, M.-C.V.; project administration, M.-C.V. and A.M.; funding acquisition, H.J., C.G., A.M. and M.-C.V.

Funding: This study was supported by the Canada Research Chair in Genomics Applied to Nutrition and Metabolic Health and from grants from the Canadian Institutes of Health Research (CIHR MOP-209380 and FH4-119922).

Acknowledgments: The authors thank participants in the study for their excellent collaboration. We would like to thank Véronique Garneau, Julie Marois, and the INAF clinical investigation unit personnel for their participation in the recruitment of the participants, the study coordination, and the data collection. We acknowledge the contribution of the McGill University and Génome Quebec Innovation Centre for gene expression array processing. M.C.V. is a Canada Research Chair in Genomics Applied to Nutrition and Metabolic Health.

Conflicts of Interest: The authors declare no conflict of interest. The funders had no role in the design of the study; in the collection, analyses, or interpretation of data; in the writing of the manuscript, or in the decision to publish the results.

\section{Abbreviations}

$\begin{array}{ll}\text { 25(OH)D } & \text { 25-hydroxyvitamin D } \\ \text { ANOVA } & \text { Analysis of variance } \\ \text { AUC } & \text { Areas under the curve } \\ \text { BMI } & \text { Body mass index } \\ \text { BPH } & \text { Bonito fish peptide hydrolysate } \\ \text { C } & \text { Cholesterol } \\ \text { CACT } & \text { Carnitine acylcarnitine translocase } \\ \text { CEBPA } & \text { CCAAT enhancer binding protein alpha } \\ \text { CPT1A } & \text { Carnitine palmitoyltransferase 1A } \\ \text { CRP } & \text { C-reactive protein } \\ \text { CVD } & \text { Cardiovascular disease } \\ \text { DBP } & \text { Diastolic blood pressure } \\ \text { DHA } & \text { Docosahexaenoic acid } \\ \text { EPA } & \text { Eicosapentaenoic acid } \\ \text { FDR } & \text { False discovery rate } \\ \text { HDL-C } & \text { High-density lipoprotein cholesterol } \\ \text { iAUC } & \text { Incremental areas under the curve } \\ \text { INAF } & \text { Institute of Nutrition and Functional Food } \\ \text { LDL-C } & \text { Low-density lipoprotein cholesterol } \\ \text { OGTT } & \text { Oral glucose tolerance test } \\ \text { PLA2G7 } & \text { Phospholipase A2 group VII } \\ \text { PLIN2 } & \text { Perilipin 2 } \\ \text { RCT } & \text { Randomized controlled trial } \\ \text { SBP } & \text { Systolic blood pressure } \\ \text { SCIMP } & \text { SLP adaptor and CSK interacting membrane protein } \\ \text { SLC25A20 } & \text { Solute carrier family 25 member 20 } \\ \text { T2D } & \text { Type 2 diabetes } \\ \text { TG } & \text { Triglyceride } \\ \text { TF } & \text { Transcription factor } \\ \text { Total-C } & \text { Total cholesterol } \\ \text { VitD } 3 & \text { cholecalciferol } \\ & \end{array}$




\section{References}

1. Mozaffarian, D. Dietary and Policy Priorities for Cardiovascular Disease, Diabetes, and Obesity. Circulation 2016, 133, 187-225. [CrossRef] [PubMed]

2. Bang, H.O.; Dyerberg, J.; Nielsen, A.B. Plasma Lipid and Lipoprotein Pattern in Greelandic West-Coast Eskimos. Nutr. Rev. 1986, 44, 143-146. [CrossRef] [PubMed]

3. Bang, H.O.; Dyerberg, J.; Sinclair, H.M. The composition of the Eskimo food in north Western Greenland. Am. J. Clin. Nutr. 1980, 33, 2657-2661. [CrossRef] [PubMed]

4. Albert, C.M.; Hennekens, C.H.; O’Donnell, C.J.; Ajani, U.A.; Carey, V.J.; Willett, W.C.; Ruskin, J.N.; Manson, J.A.E. Fish consumption and risk of sudden cardiac death. J. Am. Med. Assoc. 1998, 279, $23-28$. [CrossRef]

5. Zhao, L.-G.; Sun, J.-W.; Yang, Y.; Ma, X.; Wang, Y.-Y.; Xiang, Y.-B. Fish consumption and all-cause mortality: A meta-analysis of cohort studies. Eur. J. Clin. Nutr. 2016, 70, 155-161. [CrossRef]

6. Jayedi, A.; Shab-Bidar, S.; Eimeri, S.; Djafarian, K. Fish consumption and risk of all-cause and cardiovascular mortality: A dose-response meta-analysis of prospective observational studies. Public Health Nutr. 2018, 21, 1297-1306. [CrossRef] [PubMed]

7. Wallin, A.; Di Giuseppe, D.; Orsini, N.; Patel, P.S.; Forouhi, N.G.; Wolk, A. Fish consumption, dietary long-chain n-3 fatty acids, and risk of type 2 diabetes: Systematic review and meta-analysis of prospective studies. Diabetes Care 2012, 35, 918-929. [CrossRef] [PubMed]

8. Vázquez, C.; Botella-Carretero, J.I.; Corella, D.; Fiol, M.; Lage, M.; Lurbe, E.; Richart, C.; Fernández-Real, J.M.; Fuentes, F.; Ordóñez, A.; et al. White fish reduces cardiovascular risk factors in patients with metabolic syndrome: The WISH-CARE study, a multicenter randomized clinical trial. Nutr. Metab. Cardiovasc. Dis. 2014, 24, 328-335. [CrossRef] [PubMed]

9. Chiesa, G.; Busnelli, M.; Manzini, S.; Parolini, C. Nutraceuticals and bioactive components from fish for dyslipidemia and cardiovascular risk reduction. Mar. Drugs 2016, 14, 113. [CrossRef] [PubMed]

10. Lee, J.E.; McLerran, D.F.; Rolland, B.; Chen, Y.; Grant, E.J.; Vedanthan, R.; Inoue, M.; Tsugane, S.; Gao, Y.T.; Tsuji, I.; et al. Meat intake and cause-specific mortality: A pooled analysis of Asian prospective cohort studies. Am. J. Clin. Nutr. 2013, 98, 1032-1041. [CrossRef]

11. Wang, M.P.; Thomas, G.N.; Ho, S.Y.; Lai, H.K.; Mak, K.H.; Lam, T.H. Fish Consumption and Mortality in Hong Kong Chinese-the LIMOR Study. Ann. Epidemiol. 2011, 21, 164-169. [CrossRef] [PubMed]

12. Osler, M.; Andreasen, A.H.; Hoidrup, S. No inverse association between fish consumption and risk of death from all-causes, and incidence of coronary heart disease in middle-aged, Danish adults. J. Clin. Epidemiol. 2003, 56, 274-279. [CrossRef]

13. Olsen, A.; Egeberg, R.; Halkjær, J.; Christensen, J.; Overvad, K.; Tjønneland, A. Healthy aspects of the Nordic diet are related to lower total mortality. J. Nutr. 2011, 141, 639-644. [CrossRef]

14. Ouellet, V.; Weisnagel, S.J.; Marois, J.; Bergeron, J.; Julien, P.; Gougeon, R.; Tchernof, A.; Holub, B.J.; Jacques, H. Dietary Cod Protein Reduces Plasma C-Reactive Protein in Insulin-Resistant Men and Women1. J. Nutr. 2008, 138, 2386-2391. [CrossRef] [PubMed]

15. Ouellet, V.; Marois, J.; Weisnagel, S.J.; Jacques, H. Dietary cod protein improves insulin sensitivity in insulin-resistant men and women: A randomized controlled trial. Diabetes Care 2007, 30, $2816-2821$. [CrossRef]

16. Vikoren, L.A.; Nygård, O.K.; Lied, E.; Rostrup, E.; Gudbrandsen, O.A. A randomised study on the effects of fish protein supplement on glucose tolerance, lipids and body composition in overweight adults. Br. J. Nutr. 2013, 109, 648-657. [CrossRef] [PubMed]

17. Tanaka, H.; Watanabe, K.; Ma, M.; Hirayama, M.; Kobayashi, T.; Oyama, H.; Sakaguchi, Y.; Kanda, M.; Kodama, M.; Aizawa, Y. The Effects of $\gamma$-Aminobutyric Acid, Vinegar, and Dried Bonito on Blood Pressure in Normotensive and Mildly or Moderately Hypertensive Volunteers. J. Clin. Biochem. Nutr. 2009, 45, 93-100. [CrossRef]

18. Tremblay, F.; Lavigne, C.; Jacques, H.; Marette, A. Role of Dietary Proteins and Amino Acids in the Pathogenesis of Insulin Resistance. Annu. Rev. Nutr. 2007, 27, 293-310. [CrossRef] [PubMed]

19. El Khoury, D.; Anderson, G.H. Recent advances in dietary proteins and lipid metabolism. Curr. Opin. Lipidol. 2013, 24, 207-213. [CrossRef] [PubMed] 
20. Chevrier, G.; Mitchell, P.L.; Rioux, L.-E.; Hasan, F.; Jin, T.; Roblet, C.R.; Doyen, A.; Pilon, G.; St-Pierre, P.; Lavigne, C.; et al. Low-Molecular-Weight Peptides from Salmon Protein Prevent Obesity-Linked Glucose Intolerance, Inflammation, and Dyslipidemia in LDLR-/-/ApoB100/100 Mice. J. Nutr. 2015, 145, 1415-1422. [CrossRef]

21. Pilon, G.; Ruzzin, J.; Rioux, L.E.; Lavigne, C.; White, P.J.; Frøyland, L.; Jacques, H.; Bryl, P.; Beaulieu, L.; Marette, A. Differential effects of various fish proteins in altering body weight, adiposity, inflammatory status, and insulin sensitivity in high-fat-fed rats. Metabolism 2011, 60, 1122-1130. [CrossRef]

22. Pilz, S.; Verheyen, N.; Grübler, M.R.; Tomaschitz, A.; März, W. Vitamin D and cardiovascular disease prevention. Nat. Rev. Cardiol. 2016, 13, 404-417. [CrossRef]

23. Jorde, R.; Grimnes, G. Vitamin D and metabolic health with special reference to the effect of vitamin D on serum lipids. Prog. Lipid Res. 2011, 50, 303-312. [CrossRef]

24. Gagnon, C.; Lu, Z.X.; Magliano, D.J.; Dunstan, D.W.; Shaw, J.E.; Zimmet, P.Z.; Sikaris, K.; Grantham, N.; Ebeling, P.R.; Daly, R.M. Serum 25-Hydroxyvitamin D, Calcium Intake, and Risk of Type 2 Diabetes After 5 Years. Diabetes Care 2011, 34, 1133-1138. [CrossRef]

25. Gagnon, C.; Lu, Z.X.; Magliano, D.J.; Dunstan, D.W.; Shaw, J.E.; Zimmet, P.Z.; Sikaris, K.; Ebeling, P.R.; Daly, R.M. Low serum 25-hydroxyvitamin D is associated with increased risk of the development of the metabolic syndrome at five years: Results from a national, population-based prospective study (The Australian Diabetes, Obesity and Lifestyle Study: AusDiab). J. Clin. Endocrinol. Metab. 2012, 97, 1953-1961. [CrossRef] [PubMed]

26. Holick, M.F. Vitamin D deficiency. N. Engl. J. Med. 2007, 357, 266-281. [CrossRef] [PubMed]

27. World Health Organization. Prevention and Management of Osteoporosis: Report of a WHO Scientific Group; World Health Organization: Geneva, Switzerland, 2003; ISBN 9241209216. Available online: https: //apps.who.int/iris/bitstream/handle/10665/42841/WHO_TRS_921.pdf (accessed on 18 December 2018).

28. Pilz, S.; Gaksch, M.; Kienreich, K.; Grübler, M.; Verheyen, N.; Fahrleitner-Pammer, A.; Treiber, G.; Drechsler, C.; Ó Hartaigh, B.; Obermayer-Pietsch, B.; et al. Effects of Vitamin D on Blood Pressure and Cardiovascular Risk Factors: A Randomized Controlled Trial. Hypertension 2015, 65, 1195-1201. [CrossRef] [PubMed]

29. Ponda, M.P.; Dowd, K.; Finkielstein, D.; Holt, P.R.; Breslow, J.L. The short-term effects of vitamin d repletion on cholesterol: A randomized, placebo-controlled trial. Arterioscler. Thromb. Vasc. Biol. 2012, 32, 2510-2515. [CrossRef] [PubMed]

30. Wang, H.; Xia, N.; Yang, Y.; Peng, D.-Q. Influence of vitamin D supplementation on plasma lipid profiles: A meta-analysis of randomized controlled trials. Lipids Health Dis. 2012, 11, 42. [CrossRef] [PubMed]

31. Sun, X.; Cao, Z.B.; Tanisawa, K.; Ito, T.; Oshima, S.; Higuchi, M. Vitamin D supplementation reduces insulin resistance in Japanese adults: A secondary analysis of a double-blind, randomized, placebo-controlled trial. Nutr. Res. 2016, 36, 1121-1129. [CrossRef]

32. El Hajj, C.; Chardigny, J.M.; Boirie, Y.; Yammine, K.; Helou, M.; Walrand, S. Effect of Vitamin D Treatment on Glucose Homeostasis and Metabolism in Lebanese Older Adults: A Randomized Controlled Trial. J. Nutr. Heal. Aging 2018, 22, 1128-1132. [CrossRef] [PubMed]

33. Gulseth, H.L.; Wium, C.; Angel, K.; Eriksen, E.F.; Birkeland, K.I. Effects of Vitamin D supplementation on insulin sensitivity and insulin secretion in subjectswith type 2 diabetes and Vitamin D deficiency: A randomized controlled trial. Diabetes Care 2017, 40, 872-878. [CrossRef] [PubMed]

34. Muscogiuri, G.; Annweiler, C.; Duval, G.; Karras, S.; Tirabassi, G.; Salvio, G.; Balercia, G.; Kimball, S.; Kotsa, K.; Mascitelli, L.; et al. Vitamin D and cardiovascular disease: From atherosclerosis to myocardial infarction and stroke. Int. J. Cardiol. 2017, 230, 577-584. [CrossRef]

35. Berlanga-Taylor, A.J.; Plant, K.; Dahl, A.; Lau, E.; Hill, M.; Sims, D.; Heger, A.; Emberson, J.; Armitage, J.; Clarke, R.; et al. Genomic Response to Vitamin D Supplementation in the Setting of a Randomized, Placebo-Controlled Trial. EBioMedicine 2018. [CrossRef] [PubMed]

36. Einarsdottir, E.; Pekkinen, M.; Krjutskov, K.; Katayama, S.; Kere, J.; Makitie, O.; Viljakainen, H. A preliminary transcriptome analysis suggests a transitory effect of vitamin D on mitochondrial function in obese young Finnish subjects. Endocr. Connect. 2019. [CrossRef] [PubMed]

37. Hossein-nezhad, A.; Spira, A.; Holick, M.F. Influence of Vitamin D Status and Vitamin D3 Supplementation on Genome Wide Expression of White Blood Cells: A Randomized Double-Blind Clinical Trial. PLoS ONE 2013, 8, e58725. [CrossRef] [PubMed] 
38. Pasing, Y.; Fenton, C.G.; Jorde, R.; Paulssen, R.H. Changes in the human transcriptome upon vitamin D supplementation. J. Steroid Biochem. Mol. Biol. 2017, 173, 93-99. [CrossRef]

39. Punthakee, Z.; Goldenberg, R.; Katz, P. Definition, Classification and Diagnosis of Diabetes, Prediabetes and Metabolic Syndrome. Can. J. Diabetes 2018, 42, S10-S15. [CrossRef]

40. Schwetz, V.; Scharnagl, H.; Trummer, C.; Stojakovic, T.; Pandis, M.; Grübler, M.R.; Verheyen, N.; Gaksch, M.; Zittermann, A.; Aberer, F.; et al. Vitamin D supplementation and lipoprotein metabolism: A randomized controlled trial. J. Clin. Lipidol. 2018, 12, 588-596. [CrossRef] [PubMed]

41. Jafari, T.; Fallah, A.A.; Barani, A. Effects of vitamin D on serum lipid profile in patients with type 2 diabetes: A meta-analysis of randomized controlled trials. Clin. Nutr. 2016, 35, 1259-1268. [CrossRef]

42. Larriba, M.J.; González-Sancho, J.M.; Bonilla, F.; Muñoz, A. Interaction of vitamin D with membrane-based signaling pathways. Front. Physiol. 2014, 5, 1-10. [CrossRef] [PubMed]

43. Drynan, L.; Quant, P.A.; Zammit, V.A. Flux control exerted by mitochondrial outer membrane carnitine palmitoyltransferase over beta-oxidation, ketogenesis and tricarboxylic acid cycle activity in hepatocytes isolated from rats in different metabolic states. Biochem.J. 1996, 317, 791-795. [CrossRef]

44. Bonnefont, J.P.; Djouadi, F.; Prip-Buus, C.; Gobin, S.; Munnich, A.; Bastin, J. Carnitine palmitoyltransferases 1 and 2: Biochemical, molecular and medical aspects. Mol. Aspects Med. 2004, 25, 495-520. [CrossRef] [PubMed]

45. Caimari, A.; Oliver, P.; Rodenburg, W.; Keijer, J.; Palou, A. Slc27a2 expression in peripheral blood mononuclear cells as a molecular marker for overweight development. Int. J. Obes. 2010, 34, 831-839. [CrossRef]

46. Reynés, B.; García-Ruiz, E.; Palou, A.; Oliver, P. The intake of high-fat diets induces an obesogenic-like gene expression profile in peripheral blood mononuclear cells, which is reverted by dieting. Br. J. Nutr. 2016, 115, 1887-1895. [CrossRef] [PubMed]

47. Saneei, P.; Salehi-Abargouei, A.; Esmaillzadeh, A. Serum 25-hydroxy vitamin D levels in relation to body mass index: A systematic review and meta-analysis. Obes. Rev. 2013, 14, 393-404. [CrossRef] [PubMed]

48. Neme, A.; Seuter, S.; Malinen, M.; Nurmi, T.; Tuomainen, T.P.; Virtanen, J.K.; Carlberg, C. In vivo transcriptome changes of human white blood cells in response to vitamin D. J. Steroid Biochem. Mol. Biol. 2019, 188, 71-76. [CrossRef]

49. Larrick, B.M.; Kim, K.H.; Donkin, S.S.; Teegarden, D. 1,25-Dihydroxyvitamin D regulates lipid metabolism and glucose utilization in differentiated 3T3-L1 adipocytes. Nutr. Res. 2018, 58, 72-83. [CrossRef] [PubMed]

50. Santos, R.K.F.; Brandão-Lima, P.N.; Tete, R.M.D.D.; Freire, A.R.S.; Pires, L.V. Vitamin D ratio and glycaemic control in individuals with type 2 diabetes mellitus: A systematic review. Diabetes. Metab. Res. Rev. 2018, 34, e2969. [CrossRef]

51. Sulaiman Al-Shoumera, K.A.A.; Al-Asoosib, A.A.; Ali, A.H.; Nair, V.S. Does insulin resistance in type 2 diabetes alter vitamin D status? Prim. Care Diabetes 2013, 7, 283-287. [CrossRef] [PubMed]

52. Mackawy, A.M.H.; Badawi, M.E.H. Association of vitamin D and vitamin D receptor gene polymorphisms with chronic inflammation, insulin resistance and metabolic syndrome components in type 2 diabetic Egyptian patients. Meta Gene 2014, 2, 540-556. [CrossRef] [PubMed]

53. Pittas, A.G.; Harris, S.S.; Stark, P.C.; Dawson-Hughes, B. The effects of calcium and vitamin D supplementation on blood glucose and markers of inflammation in nondiabetic adults. Diabetes Care 2007, 30, 980-986. [CrossRef]

54. Tsukada, J.; Yoshida, Y.; Kominato, Y.; Auron, P.E. The CCAAT/enhancer (C/EBP) family of basic-leucine zipper (bZIP) transcription factors is a multifaceted highly-regulated system for gene regulation. Cytokine 2011, 54, 6-19. [CrossRef] [PubMed]

55. Robitaille, J.; Després, J.-P.; Pérusse, L.; Vohl, M.-C. The PPAR-gamma P12A polymorphism modulates the relationship between dietary fat intake and components of the metabolic syndrome: Results from the Québec Family Study. Clin. Genet. 2003, 63, 109-116. [CrossRef]

56. Taylor, H.L.; Jacobs, D.R.; Schucker, B.; Knudsen, J.; Leon, A.S.; Debacker, G. A questionnaire for the assessment of leisure time physical activities. J. Chronic Dis. 1978, 31, 741-755. [CrossRef]

57. Goulet, J.; Nadeau, G.; Lapointe, A.; Lamarche, B.; Lemieux, S. Validity and reproducibility of an interviewer-administered food frequency questionnaire for healthy French-Canadian men and women. Nutr. J. 2004, 3, 13. [CrossRef] [PubMed] 
58. Ledue, T.B.; Weiner, D.L.; Sipe, J.D.; Poulin, S.E.; Collins, M.F.; Rifai, N. Analytical evaluation of particleenhanced immunonephelometric assays for C-reactive protein, serum amyloid A and mannose-binding protein in human serum. Ann. Clin. Biochem. 1998, 35, 745-753. [CrossRef]

59. Vossen, M.; Tödter, K.; Altenburg, C.; Beisiegel, U.; Scheja, L. Plasma triglycerides after oral glucose load specifically associate with metabolic risk markers in healthy type 2 diabetes offspring. Atherosclerosis 2011, 217, 214-219. [CrossRef]

60. Buchanan, J.R.; Santen, R.; Cauffman, S.; Cavaliere, A.; Greer, R.B.; Demers, L.M. The effect of endogenous estrogen fluctuation on metabolism of 25-hydroxyvitamin D. Calcif. Tissue Int. 1986, 39, 139-144. [CrossRef] [PubMed]

61. Gaujoux, R.; Seoighe, C. CellMix: A comprehensive toolbox for gene expression deconvolution. Bioinformatics 2013, 29, 2211-2212. [CrossRef] [PubMed]

62. Phipson, B.; Lee, S.; Majewski, I.J.; Alexander, W.S.; Smyth, G.K. Robust hyperparameter estimation protects against hypervariable genes and improves power to detect differential expression. Ann. Appl. Stat. 2016, 10, 946-963. [CrossRef] [PubMed]

(C) 2019 by the authors. Licensee MDPI, Basel, Switzerland. This article is an open access article distributed under the terms and conditions of the Creative Commons Attribution (CC BY) license (http://creativecommons.org/licenses/by/4.0/). 